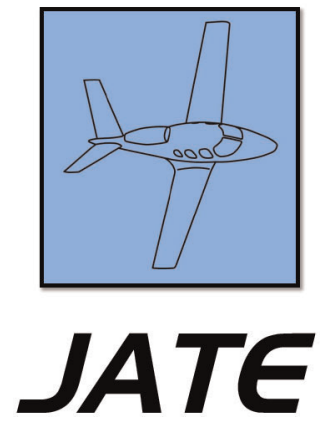

Journal of Aviation Technology and Engineering 6:1 (2016) 25-33

\title{
Two Decades of Progress for Minorities in Aviation
}

\author{
David C. Ison, Rene Herron, and Linda Weiland \\ Embry-Riddle Aeronautical University-Worldwide
}

\begin{abstract}
Diversity within the science, technology, engineering, and mathematics (STEM) fields has historically lagged behind that which is found in other vocational paths. Aviation has also suffered poor diversity with virtually no participation among professional pilots. With both the literature specifying the benefits of diversity in the aviation workplace and potential shortages of pilots looming, it is in the interest of aerospace stakeholders to have access to the most comprehensively diverse employee pool possible. The purpose of this research was to evaluate the trends in participation by minorities who completed professional pilot education programs in the United States. Data concerning the number of students who completed degrees at the associate's, bachelor's, and master's levels were collected via the Integrated Postsecondary Education Data System (IPEDS). Participation rates were compared to those found within the aviation industry. In general, the participation rates by non-White minorities in collegiate aviation (27.3\%) exceeds that reported in the professional pilot vocation (18.4\%). Detailed trends over the past 10 years were evaluated. Between 2004 and 2014, minority (including women) participation increased from $17.1 \%$ to $22.2 \%$, which was deemed to be statistically significant $(z=3.7, p<0.001)$. The greatest gains were exhibited among Hispanics $(p<0.001)$, specifically Hispanic men $(p<0.001)$, with marginal gains by Asians $(p=0.06)$. Decreases were noted in Native American participation $(p=0.03)$ as well as among women, albeit not significantly $(p=0.31)$. When extending the analysis back another seven years, minority (including women) participation showed significant change from 1997 (16.5\%) to 2014 (22.2\%), $z=3.7, p<0.001$. Minority participation in professional pilot education has shown steady gains over the past two decades; however, it appears that this trend is leveling, especially among women. Further study is recommended with particular interest in promotion and recruitment of a diverse aviation student population.
\end{abstract}

Keywords: aviation, women, minorities, participation, inclusion, higher education, statistics

While the demographic landscape of the United States has been constantly changing since the inception of the country, the level of diversity within the population has been rapidly accelerating over the past several decades (Toossi, 2002). According to the 2010 census report, the percentage of White-alone Americans was $75.1 \%$ in 2000 and dropped $2.7 \%$ by 2010 to $72.4 \%$. During this same time period, Blacks, Asians, and Hispanics each increased by $0.3 \%, 1.2 \%$, and $3.8 \%$ respectively (US Census Bureau, 2015). The US Department of Labor predicted that by $202423 \%$ of the population will fall within a minority category. Whites are expected to account for $77 \%$ of the labor force, while Blacks will increase from $0.6 \%$ to $12.7 \%$, Asians will increase from $1 \%$ to $6.6 \%$, and all other groups will increase from $0.5 \%$ to $3.7 \%$ (BLS, $2015 \mathrm{a}$ ).

Increased diversity has slowly permeated into a variety of facets of American society, from participation in the labor force to all levels of education. From 1990 to 2010, the White labor force grew by $16.4 \%$, yet the Black labor force grew by $30 \%$, 
and the Asian labor force increased by 55.8\%. The Hispanic labor force tripled during this period. Female participation jumped $26.5 \%$ vis-a-vis an increase of $18.8 \%$ among males (Toossi, 2012). Among four-year higher education institutions, similar trends have been identified. In 1961, 97\% of students were White, $2 \%$ were Black, and less than $1 \%$ were Asian. Forty-four percent of students at that time were women. By 1984, women outnumbered men, representing 52\% of students. Additionally, $86 \%$ were White, $10 \%$ Black, $1 \%$ Native American, 2\% Asian, and 2\% Hispanic (Altback, Berdahl, \& Gumport, 2005). From 1998 to 2008, there was a $31.7 \%$ increase in overall enrollments with a 14\% increase among Whites, 55.2\% among Blacks, 74.4\% among Hispanics, 37.4\% among Asians, 30.4\% among Native Americans, and 34\% among women (Kim, 2012). This surge is also seen in numbers collected from the National Center for Education Statistics (NCES) report that examined the 1990-2012 years. The number of Whites enrolled in degree-granting postsecondary institutions fell from $79.9 \%$ to $60.3 \%$. Increases were seen in Blacks, 9.3\% to $14.9 \%$; Asians, $4.3 \%$ to $6.3 \%$; Hispanics, $5.8 \%$ to $15 \%$; and other races and ethnicities, $0.8 \%$ to $0.9 \%$ (NCES, 2015a).

Even in light of these improvements, there are certain fields and areas of study in which minorities have consistently been underrepresented and in which growth rates in participation have historically lagged. One such example of underrepresentation is within the science, technology, engineering, and mathematics (STEM) fields (American Institutes for Research, 2012). Exploring these subject threads further, it is evident that few minorities are involved in the aviation industry. Among aircraft pilots, minority participation has been virtually nonexistent with principally diminutive participation rates (Hedge, 2008).

There is much within the extant literature that highlights the benefits of minority participation in the workplace as well as in higher education particularly within STEM programs (McMahon, 2010; Umbach, 2006). These studies outline benefits of diversity that include more positive work conditions, potential competitive business advantages, and richer learning environments (Lockwood, 2005; Umbach, 2006; Willdorf, 2000). Such diversity has been identified to be particularly important in fields in which few minorities are involved (Luedtke, 1993). In the case of education, it is argued that "with racial, ethnic, and gender diversity comes a diversity of life experiences, values, and ideas, and exposing students to these various perspectives has educational benefits" (Maranto, Redding, \& Hess, 2009, p. 102). The importance of diversity has received strong support from the federal government as well as the justice system of the United States. In 2003, the US Supreme Court decided in Grutter v. Bollinger that because of the positive influences of diversity, efforts to promote increased access to education by minorities merit affirmative action (Maranto, Redding, \& Hess, 2009). Diversity enhancement has also been supported by institutional policies, which are often supported by federal aid (Altbach, Berdahl, \& Gumport, 2005). The benefits of diversity are also recognized in the workplace. The federal government has strict policies on encouraging the participation of minorities within its various agencies, e.g., the Federal Aviation Administration (FAA) has an Office of Civil Rights, which is charged with monitoring, encouraging, and enforcing anti-discrimination policies (FAA Office of Civil Rights, 2012).

Due to the importance of diversity in various environments, the federal government, along with a variety of organizations, has implemented a plethora of programs and initiatives to increase minority participation in specific fields with substantial attention being focused on the STEM subjects. Also, the federal government and a number of private entities have invested substantially in efforts to increase minority participation in aviation. Furthermore, there are numerous efforts to encourage the fostering of minority pilots (Corporate Social Responsibility Newswire, 2001; FAA, 2015a; Minority Aviation Education Association, n.d.; NSF, 2012; Sallie Mae Fund, 2012; Sterkenburg \& Stanley, 2002; The White House, 2003; Women in Maryland Higher Education, 2013; Wolf Aviation Fund, 2015).

Even in light of the perceived and documented advantages to having a diverse industry, few studies on the subject within the confines of collegiate aviation are available in the literature. Moreover, virtually no feedback exists for the multiplicity of programs, initiatives, and funding that exist to promote minority participation in aviation (FAA, 2015b; Ison, 2009). Considering the general changes in demographics in the US, the lack of minority participation could potentially exacerbate expected shortages of pilots (Andersen, 2016). Within the scarce literature that exists on the subject, researchers have identified the need for more inquiry into minority participation in STEM education, in an assortment of facets of aviation, in aviation higher education, and in particular among pilots (Hobbs \& Stoops, 2000; Ison, 2009; Kirschner \& Vorvoneau, 2012). To address these deficiencies in the literature and related calls for further research, this study sought to quantify the status of minorities in collegiate professional pilot programs and trends in such participation rates over the last two decades (Ison, 2009).

\section{Demography of the United States}

The demographic construct of the United States was dominated by Whites for nearly the first 200 years of the existence of the nation. Even when considering the influx of slaves and the presence of Native Americans, the demographics of individual states were at most dichotomous. In 1900, only two states north of the Mason-Dixon Line had non-White populations exceeding $10 \%$. The bulk of "diversity" at that time was a relic of slavery with Whites still being the 
majority and the other commonly encountered race being Black. Even in 1970, the US was divided mostly between Blacks and Whites with a scant $1.4 \%$ of the population falling outside these classifications (Hobbs \& Stoops, 2000).

It was not until around 1980 that the heterogeneity of the US population began to accelerate. Between 1980 and 2000 , the White population increased by $12.3 \%$ while the Black population grew by $30.8 \%$, the Asian population grew $204 \%$, the Hispanic population grew by $141.7 \%$, and the Native American population grew by $74.3 \%$ (US Department of Labor, 1999). Current data indicates that women make up half of the US population while Whites account for $62.8 \%$, Blacks $13.2 \%$, Asians $5.4 \%$, Hispanics $17.4 \%$, and Native Americans $1.2 \%$ (US Census Bureau, 2016). It is projected that by the mid- $21^{\text {st }}$ century, nonWhites will make up the majority of the population in the US (Fassinger, 2008).

\section{Review of Literature}

In order to best understand the low participation rates of women and other minorities in the American aviation industry, it is necessary to explore the historical change that has occurred with the US workforce as a whole. Next, to frame the data analysis of this study, in that collegiate aviation program completions were utilized for such inquiry, trends in women and other minority participation in higher education are outlined. Literature concerning underrepresented groups in aviation is presented to provide background on minority participation in aviation through the lens of higher education flight programs and how this data compares to what currently exists within the industry.

\section{Diversity in the Workforce}

As the population of the US has become more varied, similar changes have filtered into the workforce. In 1990, $66.9 \%$ of White non-Hispanics, $64 \%$ of Blacks, $65.4 \%$ of Asians, and $67.4 \%$ of Hispanics were active within the civilian workforce. Women of all races participated at a rate of $57.5 \%$. From 1990 to 2000, the participation rate of Whites increased $0.4 \%$, Blacks $1.8 \%$, Asians, $1.8 \%$, and Hispanics $2.3 \%$. The increase in the participation by women over this period was $2.4 \%$ (Toossi, 2012). From a different perspective, in 1997 10.8\% of the workforce was Black and $9.8 \%$ was Hispanic. By 2007, those numbers had increased to $11 \%$ and $14 \%$ respectively. Gains by women were positive but negligible. Data on Asians only became available in 2003 and from this date to 2007, there was a $0.5 \%$ increase to a total of $4.7 \%$ of the workforce. No comparable data specifically identifying Native Americans was available at this time; however, in 2012, 59.3\% of the ethic group was in the workforce. By 2012, Whites made up 64\%, Blacks 61.5\%, Asians 63.9\%, and Hispanics
$66.4 \%$ of the workforce (BLS, 2012). Although workforce projections through 2020 indicate an overall slowdown in growth, by 2050 minorities will become the majority in the workplace (Landivar, 2013).

\section{Minorities in Higher Education}

US higher education institutions have been growing at a rapid pace. From 1998 to 2008, there was a 31.7\% increase in enrollments, a $14 \%$ increase in White enrollment, and a $56.5 \%$ jump among minorities. Specifically, the number of Black students increased by $55.2 \%$, Hispanics by $74.4 \%$, Asians by $37.4 \%$, Native Americans by $30.4 \%$, and women by $34 \%$ (Kim, 2012). Since 1970, women have outnumbered men in higher education and continue to outpace men in their population growth among students (NCES, 2004). US collegiate enrollment of White students fell $24 \%$, while minority enrollments increased from 1976 to 2012. During this timeframe, the percentage of Black students rose $10 \%$ to an overall of $15 \%$. Hispanics, Asians, and other minorities increased $4 \%, 2 \%$, and $0.7 \%$ respectively (National Center of Education Statistics, 2015b).

Even in light of these improvements in minority participation in education, there are still racial and gender differences among majors, particularly in the STEM fields. In a recent study, it was shown that $77.1 \%$ of STEM students were White, while only $11.2 \%$ were Asian, $7.6 \%$ were Black, $3.8 \%$ were Hispanic, and $0.4 \%$ were Native American (Fassinger, 2008). By 2011, for those holding degrees in science and engineering disciplines $70.1 \%$ were White, $7 \%$ were Black, $13 \%$ were Asian, $0.3 \%$ were Native American, and 6.7\% were Hispanic (Landivar, 2013). Although women are currently the majority among college students, of 18-24 year olds, as of 2011, women only held $38.8 \%$ of STEM degrees and $23.7 \%$ of the workforce positions. There is much concern about the number of students entering STEM fields in the US in general, which has sunk to the number 20 rank among countries in terms of the percentage of college-aged students who were in such programs. Contributing to this concern is that the growth in higher education is among students that do not typically participate in STEM fields, indicating an unlikely ability to resolve the deficiency in the near term (Landivar, 2013; National Academy of Sciences, 2011).

\section{Diversity in the Skies: Minority Participation in Aviation}

Much like the STEM fields, aviation has historically had very few minority participants, especially as professional pilots. In fact, "U.S. airlines have employed mostly White males, and it is still the case that White males dominate the management and piloting ranks of the industry" (Hansen \& Oster, 1997, p. 115). The entire aviation profession, not solely the airlines, still has minimal participation by nonWhite and non-male employees (Ison, 2009). In 2011, of 
the 121,000 persons employed as aircraft pilots, $4.3 \%$ were women, $2.9 \%$ were Black, 2.4\% were Asian, and 3.9\% were Hispanic (BLS, 2012). By 2015, the US Bureau of Labor Statistics (BLS) showed that there were 140,000 persons employed as aircraft pilots of which $9.4 \%$ were women, $2.6 \%$ were Black, $0.7 \%$ were Asian, and $5.7 \%$ were Hispanic (BLS, 2015b). It is important to note, however, that these figures are based upon estimates extrapolated from sample data. The only other related data comes from the Federal Aviation Administration and indicates that $6.7 \%$ of pilots in 2011 were women. The number of female individuals holding pilot certificates was $6.6 \%$ by the end of 2014 , which indicates a minor drop (FAA, 2015c). A direct measure of minority participation in the pilot workforce currently does not exist.

According to Fassinger (2008), "a strong workforce [ . . ] is critical to the continued economic leadership of the United States [. . . and] the strength of the workforce depends on the full utilization of the talents, abilities, and perspectives of diverse workers" (p. 253). Following a similar philosophy, Turney (2004) noted that because of its rapidly changing, highly technical nature, coupled with fewer entrants, aviation must attract a diverse workforce to continue to thrive. Due to the recognized benefits of minority participation in aviation, a number of federal, industry, and private entities have created initiatives and incentives to increase diversity within the vocation; Congress has called for initiatives to increase minority participation in aviation overall (Ison, 2009).

In 2007, the FAA and the National Aeronautics and Space Administration (NASA) created a partnership to make improvements in STEM education and participation. Specifically, the agreement stated that the two organizations "share a common and critical goal of cultivating a diverse, qualified workforce that will develop, manage, and operate the next generations of air traffic and transportation system" (FAA, 2007, p. 22). The FAA supports a minorityserving institution intern program that "provides students from Historically Black Colleges and Universities, Hispanic Serving Institutions, students attending a college or university with a high percentage of Asian American and Pacific Islanders, Tribal Colleges and Universities, and Students with Disabilities the opportunity to participate in internship opportunities throughout the United States" (FAA, 2015b, para. 1). The FAA also has a Native American/Alaska Native (NAAN) program to assist undergraduate and graduate students of such ethnicities with a stipend, travel, assistance with housing, and incidental expenses for participants (FAA, 2015b). In 2008, the FAA signed an agreement with the Organization of Black Airline Pilots and the International Black Aerospace Council to pledge support to the organizations' various projects (Kraus, 2010).

An abundance of aviation minority organizations has emerged, each promoting participation of persons they represent. The Organization of Black Aerospace Professionals (OBAP) has a variety of education programs and, as previously mentioned, received support through agreements with the FAA (Organization of Black Aerospace Professionals, 2015). Women in Aviation International (WAI) assists in helping women become more involved in the industry through conferences, mentoring opportunities, and scholarships (WAI, 2015). The Hispanic Professional Pilots Association provides similar provisions (Hispanic Professional Pilots Association, n.d.). A number of other organizations also have scholarships and other support systems for minorities seeking careers in aviation and as pilots. Examples include the Udall Scholarship for American Indian and Alaska Native Peoples, Zonta International Amelia Earhart Fellowship awards, and the Development Fund for Black Students in Science and Technology (FAA, 2015a). A variety of collegiate aviation programs have minority scholarships and assistance available (LeTourneau University, n.d.). Five historically Black colleges joined Western Michigan University to form a Diversity in Aviation Consortium that has the goal of improving minority participation in collegiate flight programs. Further, even corporations have adopted promotions of diversity in various forms. Delta Airlines paired with Western Michigan University to train minority pilots (Corporate Social Responsibility Newswire, 2001). United Airlines and UPS both have stated commitments to providing minorities with employment and advancement opportunities within the companies (Henderson, 1995).

With the initiatives to grow minority participation in aviation, it behooves all stakeholders to evaluate if such programs are working and, if so, to what extent. However, the current literature does not adequately describe the levels of diversity; moreover, trends in participation rates are essentially unknown. In order to shed light on the changes in minority involvement over time, it is necessary to look at both historical and pipeline data. If a higher level of minorities is within the professional pilot conduit than exists in the workforce, there can be, at least, some confidence that participation rates are increasing. Because a college education has become a de facto prerequisite for a professional pilot career, enrollments in such programs can be evaluated to infer what is in store for the industry in the proximate future. Similar approaches have been used in related research and thus were adopted here (EchaoreMcDavid, 2011; Holbeche, 2006; Ison, 2009; Sethna, 2011).

\section{Method}

\section{Purpose}

The purpose of this quantitative study was to examine the current status and historical trends of minority students who graduated from an associate's, bachelor's, or master's 
professional pilot degree program in the United States from 2004 to 2014. Additionally, a comparison to earlier data from 1997 was examined for a more long-term view on this trend.

\section{Participants}

The population for this study was all students who completed an associate's, bachelor's, or master's degree in a professional pilot program at an accredited, degreegranting institution in the US. Only institutions that report to the Integrated Postsecondary Education Data System (IPEDS) were included. The IPEDS parameters that were set to determine the schools eligible for inclusion in the study are as follows:

- Data viewed by collection year

- Any state or jurisdiction

- Any geographic region

- Any sector

- Degree-granting

- Any highest degree offered

- Any institutional category

- Any Carnegie classification

- Any degree of urbanization

- Any institution size category

- US schools only

Because IPEDS does not contain specific major enrollment data, only degree completion statistics were collected. This was deemed a logical choice as such data provides better indication of those who are eligible for entering the workforce with the expected education levels. Within the completion stratus, the "Awards/degrees conferred by program (6-digit CIP code), award level and gender" (National Center for Education Statistics, custom data section) were selected. Next, the following selections were made to extract the necessary data:

- Award level: total degrees, associate's degrees, bachelor's degrees, master's degrees

- First major

- Grand total of students, total; male; female

- White, non-Hispanic students, total; male; female

- Black non-Hispanic students, total; male; female

- Hispanic students, total; male; female

- Asian or Pacific Islander students, total; male; female

- American Indian/Native Alaskan students, total; male; female

- 49-Transporation and Material Moving Workers

- 49.01-Air Transportation Workers

- 49.0102-Airline/Commercial/Professional Pilot

- 49.0108-Flight Instructor

\section{Procedure}

Data was collected with the IPEDS data center utilizing the aforementioned parameters for the most recent ten years of data (2004 to 2014). Additionally, a file was collected for 1997 for more in-depth trend analysis (note: 1997 was the first year comprehensive data was made available from IPEDS for the level of analysis undertaken by this study). The data file produced by IPEDS provided the total number of students graduating from professional pilot education programs at the associate's, bachelor's, and master's levels broken down by ethnicity and gender. Each year was stored as a separate CSV file for analysis within Microsoft Excel. Totals for each subcategory were produced through sum functions. These were utilized for the determination of descriptive statistics. Participation rates, i.e., proportions, for 1997, and 2004 through 2014 were calculated by dividing the individual ethnicity/gender total by the grand total of graduates. Chi square goodness-of-fit tests were also conducted on total enrollments to evaluate changes during the evaluated time periods (Pallant, 2007). These rates were analyzed for potential differences using a twotailed z-test for comparing two independent population proportions (Marascuilo \& Serlin, 1988).

\section{Results}

A Chi square goodness-of-fit test was conducted with the expected frequencies based upon applicable distribution of students among years analyzed, which indicated a significant increase in the numbers of minority (including women) students, $\chi^{2}(1, N=769)=41.232, p<0.001, \phi=0.23$. From 2004 to 2014, minority (including women) percentage participation increased from $17.1 \%$ to $22.2 \%$, which was deemed to be statistically significant $(z=3.7, p<$ 0.001). During the same period, the non-White participation rate increased from $17.3 \%$ to $27.3 \%$, which was also determined to be significant $(z=2.0, p=0.04)$. Each minority subset was then analyzed, a summary of which is shown in Table 1. The only individual grouping that experienced significant increases in participation rate were Hispanics (all, men, and women). When evaluating the findings with less stringent $\alpha$ levels, total Asian participation (all and women) also showed improvement $(p=0.06)$. Two sets of minorities experienced declines with the participation rate of all women dropping $1 \%(p=0.31)$ and that of Native Americans, total and men, decreasing by $0.56 \%(p=0.03)$ and $0.52 \%(p=0.03)$, respectively. Visual summaries of descriptive proportions are displayed in Figures 1 and 2.

In order to explore the more long-term changes that have occurred in minority participation in aviation, a dataset from 1997 was collected, therefore allowing an additional retrospective analysis. A Chi square goodness-of-fit test was conducted with the expected frequencies based upon 
Table 1

Statistical significance of changes in participation rates at associate's, bachelor's, and master's degree levels from 2004 to 2014.

\begin{tabular}{|c|c|c|c|c|}
\hline Classification & $\begin{array}{l}\text { Difference in \% } \\
2004 \text { to } 2014\end{array}$ & $\begin{array}{c}\text { Statistically Significant } \\
\text { @ 95\% }\end{array}$ & $z$ Score & $\begin{array}{c}p \text { Value } \\
\text { Two-Tailed }\end{array}$ \\
\hline Women - All & -1.00 & No & 1.0 & 0.31 \\
\hline Black - All & 0.29 & No & 0.6 & 0.53 \\
\hline Black - Men & 0.16 & No & 0.3 & 0.77 \\
\hline Black - Women & 0.13 & No & 1.0 & 0.30 \\
\hline Hispanic - All & 5.17 & Yes & 6.5 & $<0.001$ \\
\hline Hispanic - Men & 4.42 & Yes & 5.9 & $<0.001$ \\
\hline Hispanic - Women & 0.74 & Yes & 2.8 & 0.006 \\
\hline Asian - All & 1.03 & No & 1.9 & 0.06 \\
\hline Asian - Men & 0.75 & No & 1.4 & 0.15 \\
\hline Asian - Women & 0.28 & No & 1.8 & 0.06 \\
\hline Native American - All & -0.56 & Yes & 2.2 & 0.03 \\
\hline Native American - Men & -0.52 & Yes & 2.2 & 0.03 \\
\hline Native American - Women & -0.04 & No & 0.8 & 0.44 \\
\hline
\end{tabular}

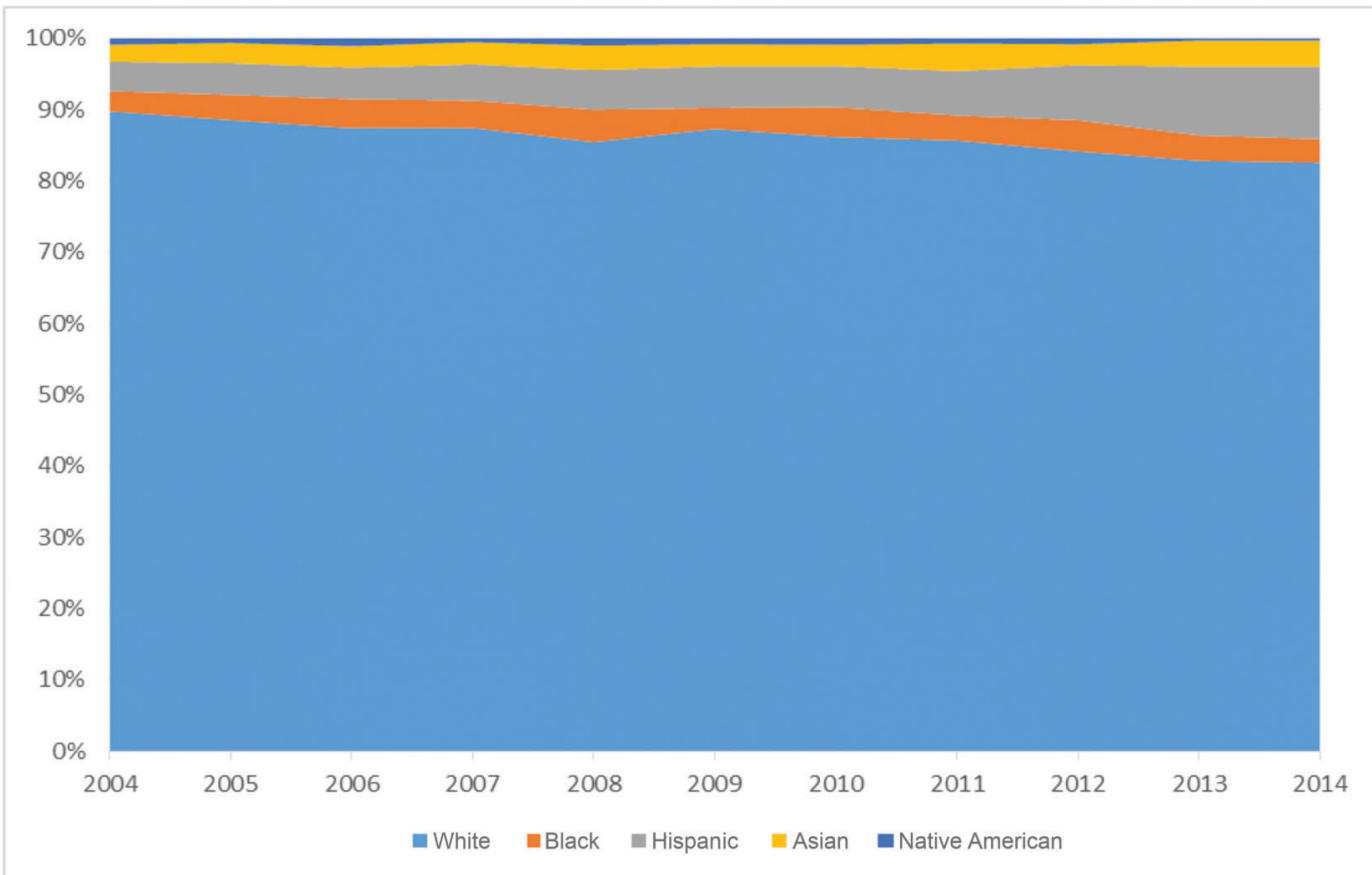

Figure 1. Total percentages, broken down by ethnicity, for years 2004 to 2014.

applicable distribution of students among years analyzed. Total minority (including women) program enrollments increased, $\chi^{2}(1, N=671)=74.396, p<0.001, \phi=$ 0.332. From 1997 to 2014, minority (including women) participation increased from $16.5 \%$ to $22.2 \%$, which was also deemed to be statistically significant $(z=3.7, p<$ 0.001). Black, Asian, and Hispanic groups all experienced significant positive changes. No groups significantly decreased. A summary of changes in major classifications are displayed in Table 2.

\section{Discussion}

Current estimates of the participation rate of women in the professional pilot vocation range from $4.3 \%$ to $6.7 \%$, and that of minorities $18.4 \%$, which, in comparison to the general population, indicates that there is a low level of diversity within this sector of aviation. Yet when compared to the participation rates of women $(8.6 \%)$ and minorities (including women, 27.3\%) in collegiate professional pilot programs, it is apparent that rates in these programs are perceptibly higher. It is encouraging that even in light of nonsignificant increases in program enrollment numbers, the level of diversity is improving. Although overall minority participation increased from 2004 to 2014, it appears to be driven mostly by Hispanics and Asians, respectively. In light of the rapid growth in Hispanic participation within higher education, this should not be surprising. Yet the fact that only Hispanics showed significant improvements over this 10-year period is somewhat disconcerting. 


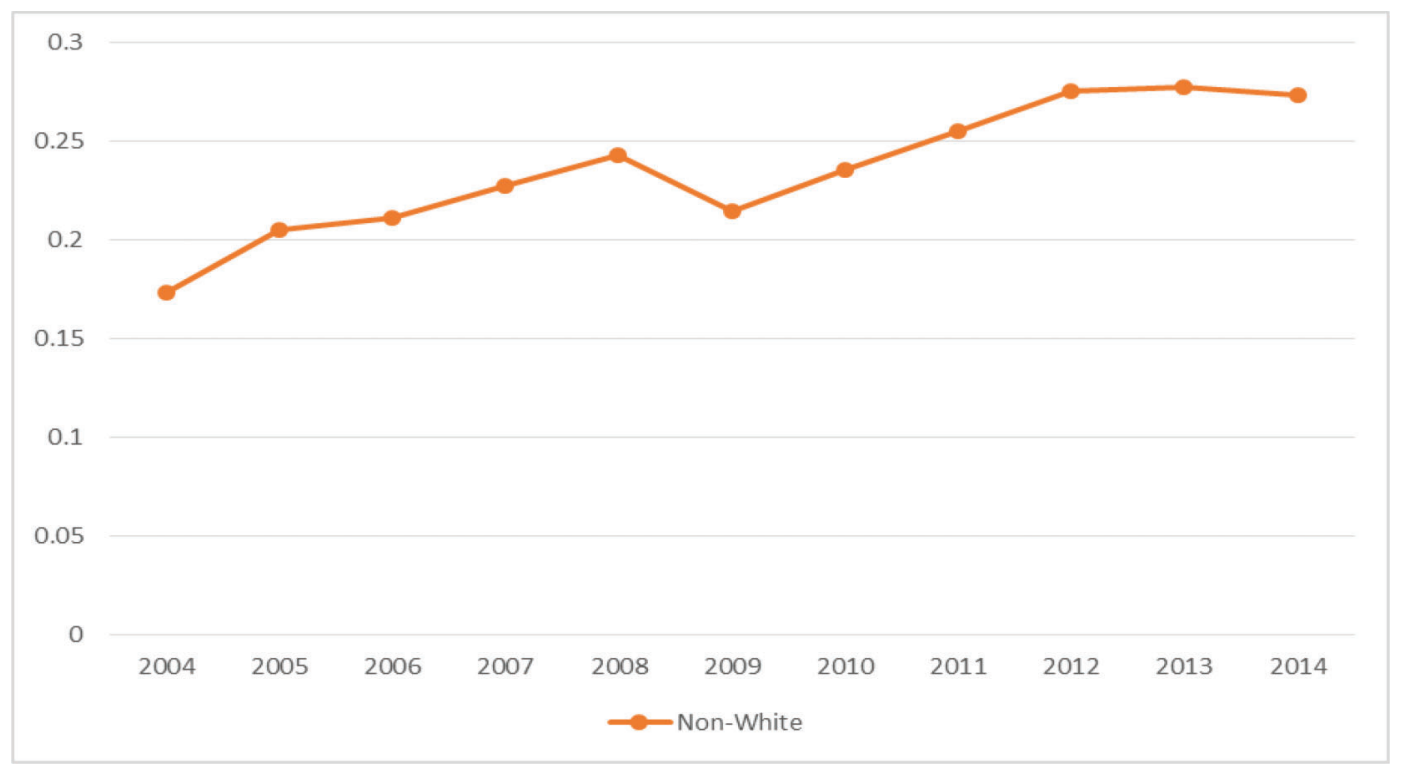

Figure 2. Total percentages of non-White participation for years 2004 to 2014.

Table 2

Statistical significance of changes in participation rates at associate's, bachelor's, and master's degree levels from 1997 to 2014.

\begin{tabular}{|c|c|c|c|c|}
\hline Classification & $\begin{array}{l}\text { Difference in \% } \\
1997 \text { to } 2014\end{array}$ & $\begin{array}{c}\text { Statistically Significant } \\
\text { @ 95\% }\end{array}$ & $z$ Score & $\begin{array}{c}p \text { Value } \\
\text { Two-Tailed }\end{array}$ \\
\hline Women - All & -0.37 & No & 0.4 & 0.71 \\
\hline Black - All & 1.13 & Yes & 2.2 & 0.03 \\
\hline Hispanic - All & 4.66 & Yes & 5.6 & $<0.001$ \\
\hline Asian - All & 1.69 & Yes & 3.4 & $<0.001$ \\
\hline Native American - All & -0.61 & No & 1.8 & 0.07 \\
\hline
\end{tabular}

When looking back further, the results are more promising. Among total minority enrollments, there was an upsurge in participation rates from 1997 to 2014. There were significant increases among Blacks, Hispanics, and Asians. The visual representations offered in Figures 1 and 2 illustrate the general trend within professional pilot education. Essentially the participation rate by Whites is steadily decreasing while that by Asians and Hispanics is noticeably increasing, coupled with marginal improvement among Blacks. Unfortunately, women appear to be decreasing in number. The same trend was true for Native Americans.

In light of improvements, it is clear that participation rates by women and other minorities in professional pilot programs is below that found in higher education overall, as well as within industry. Hopefully, some trickle-down effects can take place where higher participation rates by minorities in higher education in general will influence increases in aviation higher education, which in turn will potentially lead to improved diversity within the professional pilot community. With higher participation rates within the pipeline for the industry, it is likely that this will eventually lead to improvements within the profession itself.

\section{Limitations and Delimitations}

While the data utilized in this study is collected through a rigorous, highly supervised reporting system managed by the US government, it is possible that there may be missing statistics or errors within the data. Some of the data provided by other sources may be based on census-based estimates or sampling and therefore may be subject to error. Also, the findings herein cannot be generalizable to populations outside the focus of the study (e.g., non-degree granting institutions or those outside the US).

The emphasis of this research on individuals associated with the piloting profession was chosen due to the availability of data from highly reliable sources, namely, IPEDS. Currently, there is no data collected that specifically divides out other important job functions such as aircraft technical support staff; thus it was deemed to concentrate on available discrete data. Certainly, in future studies, minority participation in other types of employment within the aviation industry should be explored; however, such examination is beyond the scope of this study. 


\section{Conclusion}

The purpose of this study was to quantify the participation rate of minorities in professional aviation as well as the trends of such rates over the past decade. Within collegiate flight programs, minorities, including women, now make up $27.3 \%$ of the student population, which clearly exceeds the approximately $18.4 \%$ participation rate within the profession. Because the trend in diversity continues to be positive, there is potential for such improvements to filter into the professional community.

Some prudence is necessary, however, as the pace of improvement appears to be slowing. While the level of progress from 1997 forward is significant on many levels, since 2004 the data has become less impressive. This data should provide some insight into what subgroups might be best targeted to bring about further gains. Another area of concern, albeit beyond the scope of this study, is that programmatic growth in general has been slothful. It would therefore be fruitful for the industry to make directed efforts to recruit more individuals into STEM and professional pilot education pipelines.

\section{Recommendations}

The findings of this study shed light onto the current status of minorities in aviation higher education and on their future participation prospects within the industry. Although minorities are certainly making interminable strides in involvement in aviation higher education, it is critical that the factors that have made this possible are retained and amplified. More importantly, the slowing of improvement should be studied in order to better understand why this has taken place. Based upon these observations, the following recommendations are made:

1. Continue efforts to recruit, mentor, and retain women and minority aviation students.

2. Conduct a broader study to investigate the participation within other parts of the aviation community such as in air traffic control, aircraft technical support, and aviation management.

3. Monitor the status of women and minority participation in aviation higher education through follow-up studies.

4. Encourage the Federal Aviation Administration to collect data on the participation of minorities among professional pilots.

5. Investigate how to improve participation rates of those groups that did not have favorable trends, such as women and Native Americans.

\section{References}

Altback, P., Berdahl, R., \& Gumport, P. (2005). American higher education in the twenty-first century: Social, political, and economic challenges $\left(2^{\text {nd }}\right.$ ed.). Baltimore: The Johns Hopkins University Press.
American Institutes for Research. (2012). Broadening participation in STEM: A call to action. Retrieved from http://www.air.org/sites/ default/files/downloads/report/Broadening_Participation_in_STEM_ Feb_14_2013_0.pdf

Andersen, B. (2016, January 28). Pilot shortage threatens to slow US airline growth. Forbes. Retrieved from http://www.forbes.com/sites/ oliverwyman/2016/01/28/pilot-shortage-threatens-to-slow-u-s-airlinegrowth/\#1209382bbb6e

Bureau of Labor Statistics (BLS). (2012). Labor force characteristics by race and ethnicity, 2011, Report 1036. Washington, DC: Author.

Bureau of Labor Statistics (BLS). (2015a). Projections of the labor force, 2014-24. Retrieved from http://www.bls.gov/careeroutlook/2015/ article/projections-laborforce.htm

Bureau of Labor Statistics (BLS). (2015b). Current population survey. Retrieved from http://www.bls.gov/cps/cpsaat11.htm

Corporate Social Responsibility Newswire. (2001, January 8). Delta, Western Michigan University announce program to boost number of women, minority pilots. CSRwire. Retrieved from http://www.csrwire. com/press_releases/26032-Delta-Western-MichiganUniversity-AnnounceProgram-To-Boost-Number-Of-Women-Minority-Pilots

Echaore-McDavid, S. (2005). Career opportunities in aviation and the aerospace industry. New York: Checkmark Books.

Fassinger, R. E. (2008). Workplace diversity and public policy: Challenges and opportunities for psychology. American Psychologist, 63(4), 2.

Federal Aviation Administration (FAA). (2007). FY 2007 performance and accountability report. Retrieved from http://www.faa.gov/about/ plans_reports/media/faa\%20fy\%2007\%20par\%20final.pdf

Federal Aviation Administration (FAA). (2015a). Minority scholarships. Retrieved from https://www.faa.gov/education/grants_and_ scholarships/minority/

Federal Aviation Administration (FAA). (2015b). Minority serving institutions (MSI) intern program. Retrieved from https://www.faa.gov/ about/office_org/headquarters_offices/ahr/jobs_careers/student_ programs/minority/

Federal Aviation Administration (FAA). (2015c). US civil airman statistics. Retrieved from http://www.faa.gov/data_research/aviation_ data_statistics/civil_airmen_statistics/

Federal Aviation Administration (FAA) Office of Civil Rights. (2012). Office of Civil Rights (ACR). http://www.faa.gov/about/office_org/ headquarters_offices/acr/

Hansen, J., \& Oster, C. (1997). Taking flight: Education and training for aviation careers. Washington, DC: The National Academy Press.

Hedge, R. (2008). A review of minority recruitment programs in aviation education (Doctoral dissertation). Retrieved from Dissertations \& Theses: A\&I database. (AAT 3291351).

Henderson, D. (1995, September). The drive for diversity. Air Transport World, 32, 33.

Hispanic Professional Pilots Association. (n.d.). About HPPA. Retrieved from https://hppa.wordpress.com/aabout-hppa/

Hobbs, F., \& Stoops, N. (2000). Demographics in the $20^{\text {th }}$ century. Washington, DC: United States Bureau of the Census.

Holbeche, L. (2006). Understanding change. Burlington, MA: ButterworthHeinemann.

Ison, D. (2009). Have we made progress? Trends in minority participation in postsecondary aviation education. Collegiate Aviation Review, 27(1), 53-64.

Kim, Y. (2012). Minorities in higher education, $24^{\text {th }}$ status report, 2011 supplement. Washington, DC: American Council on Education.

Kirschner, J., \& Vorvoneau, M. (2012). Minority persistence in a collegiate aviation program: A phenomenological ethnography. Presented at the University Aviation Association conference, Murfreesboro, TN.

Kraus, T. (2010). Celebrating a history of excellence: The Federal Aviation Administration aviation and space education outreach program. Washington, DC: Department of Transportation.

Landivar, L. C. (2013, September). Disparities in STEM employment by sex, race, and Hispanic origin, American Community Survey Reports, 
ACS-24. Washington, DC: US Census Bureau DC. Retrieved from https://www.census.gov/prod/2013pubs/acs-24.pdf

LeTourneau University. (n.d.). Available aviation scholarships. Retrieved from http://www.letu.edu/_Academics/Aero-Science/scholarships.html

Lockwood, N. (2005). Workplace diversity: Leveraging the power of difference for competitive advantage. Alexandria, VA: Society for Human Resource Development.

Luedtke, J. (1993). Maximizing participation of women in collegiate aviation education. (National Institute for Aviation Research Report 93-14). Wichita, KS: National Institute of Aviation Research.

Maranto, R., Redding, R., \& Hess, F. (Eds.). (2009). The politically correct university: Problems, scope, and reforms. Washington, DC: The AEI Press.

Marascuilo, L., \& Serlin, R. (1988). Statistical methods for the social and behavioral sciences. New York: W. H. Freeman and Company.

McMahon, A. M. (2010). Does workplace diversity matter? A survey of empirical studies on diversity and firm performance, 2000-09. Journal of Diversity Management, 5(2), 37-48

Minority Aviation Education Association. (n.d.). Camps and programs. Interactive Science Programs. Retrieved from http://www.maeaonline. org/programs.html

National Academy of Sciences. (2011). Expanding underrepresented minority participation: America's science and technology talent as the crossroads. Washington, DC: The National Academy Press.

National Center for Education Statistics (NCES). (2015a). Degree-granting institutions: Enrollment by race and ethnicity. Mobile Digest of Education Statistics. Retrieved from https://nces.ed.gov/programs/ digest/mobile/Enrollment_DGI_Enrollment_by_Race_and_Ethnicity. aspx

National Center for Education Statistics (NCES). (2015b). Digest of Education Statistics, 2013 (NCES 2015-011). Washington, DC: Author.

National Center for Education Statistics (NCES). (2004). Trends in educational equity of girls \& women, 2004. Washington, DC: Author.

National Science Foundation (NSF). (2012). Committee on equal opportunities in science and engineering (CEOSE). Retrieved from http:// www.nsf.gov/od/oia/activities/ceose/

Organization of Black Aerospace Professionals. (2015). About OBAP. Retrieved from http://www.obap.org/

Pallant, J. (2007). SPSS survival manual. Maidenhead, UK: Open University Press.

Sallie Mae Fund. (2012). About the Sallie Mae Fund. Retrieved from http://www.thesalliemaefund.org/about/

Sethna, B. (2011). Minorities in higher education: A pipeline problem? Research in Higher Education Journal, 13, 1.
Sterkenburg, R., \& Stanley, D. (2002). Introducing underrepresented minority high school students to an aeronautical technology program at Purdue University. Paper presented at the International Conference on Engineering Education, Manchester, UK.

Toossi, M. (2002). A century of change: The US labor force, 1950-2050. Washington, DC: Department of Labor Statistics.

Toossi, M. (2012). Employment outlook: 2010-2020. Labor force projections to 2020: A more slowly growing workforce. Monthly Labor Review, 1(January), 44.

Turney, M. A. (2004). Tapping diverse talent in aviation: Culture, genders, and diversity. Farnham, UK: Ashgate.

Umbach, P. (2006). The contribution of faculty of color to undergraduate education. Research in Higher Education, 47(3): 317-345.

US Census Bureau. (2015). 2010 census data products: United States. Retrieved from http://www.bls.gov/careeroutlook/2015/article/ projections-laborforce.htm

US Census Bureau. (2016). Quick facts. Retrieved from https://www. census.gov/quickfacts/table/PST045215/00

US Department of Labor. (1999). Futurework: Trends and challenges for work in the $21^{\text {st }}$ century. Washington, DC: Author.

The White House. (2003). From risk to opportunity: Fulfilling the educational needs of Hispanic Americans in the $21^{s t}$ century. Retrieved from http://govinfo.library.unt.edu/eeha/paceea/finalreport.pdf

Willdorf, N. (2000). Minority law professors said to need mentors. Chronicle of Higher Education, 46(20), A18.

Wolf Aviation Fund. (2015). Aviation and space education: A key to unlocking the future. Retrieved from http://www.wolf-aviation.org/ education.htm

Women in Aviation International (WAI). (2015). Retrieved from http:// wai.org/

Women in Maryland Higher Education. (2013). About WIMHE. Retrieved from https://www.facebook.com/Women-in-Maryland-HigherEducation-262748300464798/

Dr. David C. Ison is the research chair for the College of Aeronautics and assistant professor of aeronautics at Embry-Riddle Aeronautical University-Worldwide.

Dr. Rene Herron is associate program chair for security and emergency response, and assistant professor of security, emergency response, and interdisciplinary studies at Embry-Riddle Aeronautical UniversityWorldwide

Ms. Linda Weiland is the College of Aeronautics liaison to Embry-Riddle Asia and is assistant professor of aeronautics at Embry-Riddle Aeronautical University-Worldwide. 